\title{
Maria do Socorro Santos, um exemplo de vida, arte e trabalho na saúde mental
}

\author{
Eduardo Mourão Vasconcelos*
}

Maria do Socorro Santos foi uma usuária de serviço de saúde mental que se tornou nossa amiga, companheira da luta antimanicomial, e uma artista de mão cheia, com pinturas que a tornaram conhecida e admirada. Mas antes de tudo, era uma pessoa sensível e dona de uma enorme experiência e sabedoria sobre a vida. Tive uma convivência muito próxima com ela, como amigo pessoal, como parceiro de lutas e como andarilhos comuns no campo da arte. É pela saudade e pela gratidão de ter podido compartilhar de sua amizade, que gostaria de dizer algumas palavras sobre ela, particularmente para aqueles que não tiveram esta oportunidade de conhecê-la de perto.

Socorro nasceu no Nordeste, em 1953, em ambiente rural distante e muito pobre. Em sua história de vida, viveu na própria pele as situações mais radicais que os pobres, oprimidos(as), discriminados(as), desviantes e excluídos(as) deste país experienciam. Começou a ter problemas mentais desde cedo, e logo perdeu o suporte dos pais. Começou a frequentar a escola com muitos sacrifícios pessoais aos 8 anos, e tinha de se levantar às 5 da manhã para chegar lá a pé, voltava e trabalhava a partir do meio-dia na roça. Aos 15, foi expulsa da escola, devido aos problemas mentais. Segundo ela, a partir do que viveu nessa fase, "pobre só tem direito de passar fome e sofrer". Migrada sozinha para a cidade do Rio de Janeiro, sem ter inicialmente onde morar, conheceu aquilo que o antropólogo Roberto da Matta identifica como uma das formas mais dramáticas de opressão sociocultural neste país: ser apenas um anônimo na multidão, fora de sua terra, em uma sociedade hierárquica, na qual o poder e o apoio social dependem fundamentalmente dos laços de conhecimento pessoal. Felizmente, conseguiu trabalhar por algum tempo como auxiliar de produção e operadora de máquinas em uma metalúrgica, mas se revoltou com a intensificação do ritmo de trabalho, com o autoritarismo do supervisor e com o risco de ter um acidente na máquina perigosa que operava, e foi demitida. Expe-

\footnotetext{
* Psicólogo, cientista político, professor aposentado da UFRJ, militante antimanicomial, e no campo das artes, tem incursões na escultura e na fotografia (https://evasconcelos.art.br/). Agradeço as sugestões e a revisão do texto, feitas por Lisete Vaz, da diretoria do Instituto Franco Basaglia, professora do Curso de Terapia Ocupacional da UFRJ, e amiga muito próxima de Socorro. E-mail: emvasconcelos55@gmail.com. ORCID: https://orcid.org/0000-0002-3490-3596.
} 


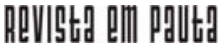

\} MARIA DO SOCORRO SANTOS - VASCONCELOS, E. M. \}

DOI: 10.12957/REP.2022.63531

rimentou também o trabalho como empregada doméstica. Uma vez, comentou rapidamente, sem dar mais detalhes, o fato de ter perdido uma filha de quatro anos, por atropelamento. Chegou a ter problemas relacionados ao uso de álcool, e em suas crises psíquicas, foi internada 25 vezes, normalmente em hospitais psiquiátricos convencionais.

Assim, quando a conhecemos, ao estigma e mortificação associados a esta condição de psiquiatrizada, se expressavam também todas as outras formas de opressão e discriminação: a de ser mulher, negra, migrada, pobre, de baixa escolaridade, e sem família. Contudo, à medida que a reforma psiquiátrica foi tomando corpo e sendo implementada no país, Socorro pôde vivenciar também um pouco daquilo pelo que lutamos: a construção de formas concretas de solidariedade e dignidade para os até então chamados apenas de loucos e "doentes mentais", e a possibilidade de recuperar, ao seu próprio ritmo e forma, uma vida pessoal ativa, singular, cheia de novos significados, e participativa na sociedade. Este processo se iniciou no Hospital de Jurujuba, em Niterói, estado do Rio de Janeiro, quando ali se iniciaram os primeiros dispositivos internos de mudança e de implementação de serviços extra-hospitalares. Socorro depois vivenciou os serviços de saúde mental abertos e comunitários, os nossos centros de atenção psicossocial, nos quais avançou seu processo de recuperação. Lá percebeu e desenvolveu suas vocações pessoais, dentre as quais a de imensa solidariedade e formas de apoio mútuo para seus companheiros, as(os) usuárias(os) de serviços, em suas dificuldades do dia a dia, e principalmente - a grande paixão de sua vida -, a pintura.

Neste caminho, foi adotada pelo antigo Instituto Franco Basaglia (IFB), conhecida ONG da luta antimanicomial e de defesa dos direitos no campo da saúde mental na cidade do Rio, na qual encontrou um verdadeiro acolhimento, pôde consolidar seu processo de recuperação e desenvolver seu trabalho de apoio mútuo e pintura, como também abraçando de corpo e alma a causa da Luta Antimanicomial. No IFB, tendo assumido um dos cargos de diretoria na função de primeira secretária, realizava trabalhos de apoio administrativo, e principalmente, atividades de suporte mútuo e de desenvolvimento da autonomia entre usuárias(os) e familiares, bem como exercia o papel de representante destes junto a órgãos públicos e de formação profissional. Por exemplo, não era raro achá-la dando palestras para alunos de graduação e profissionais formados, das áreas de psicologia, enfermagem, serviço social, psiquiatria, terapia ocupacional e outras profissões, quando falava da visão das(os) usuárias(os) e familiares, e de como gostariam que fossem tratados nos serviços e no trabalho profissional no campo da saúde mental. Sobre esta sua luta, ela mesma afirmava: "queremos uma sociedade em que ninguém vai te excluir, mas sim incluir. A nossa sociedade vai ser igual à sociedade de cada um". Participou de inúmeros encontros regionais e nacionais da luta antimanicomial, até mesmo representando o IFB. A partir de 2001, nós, do Projeto Transversões, da Escola de Serviço 


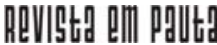

\} MARIA DO SOCORRO SANTOS - VASCONCELOS, E. M. \}

DOI: $10.12957 /$ REP.2022. 63531

Social da UFRJ, também a adotamos, e com ela vínhamos desenvolvendo algumas idéias e projetos, particularmente na promoção de sua pintura.

Visionária, Socorro morou sozinha durante um bom tempo, tendo criado em sua casa um acolhedor, responsável e cuidadoso ambiente semeIhante ao dos Serviços Residenciais Terapêuticos que começavam a ser implantados em nosso país. Ali abrigava temporariamente e espontaneamente usuárias(os) amigas(os) que estivessem sem lugar para dormir. Solidária e assertiva, como na vida, dava as regras de convivência: "não durma tarde;...tome seu remédio... amanhã trabalho cedo e preciso dormir cedo..." Referia-se à pintura, às longas horas que passava trabalhando em suas pinturas.

Em todo este percurso, Socorro conquistou parte daquilo que a vida Ihe negara. Ela dizia que nós, amigos e companheiros do IFB, do Transversões, da luta antimanicomial e das oficinas de pintura e teatro, éramos a sua verdadeira família, a que substituía aquela dos laços de sangue, que ela nunca pôde vivenciar. Não menosprezou seu modo de estar na vida. Em conversa sempre informal e sempre preciosa, ela nos disse: "loucura...não pedi, não comprei, não roubei. Loucura é patrimônio, é troféu; não vendo, não troco; não dou para ninguém."

Mas temos que reconhecer que talvez a vida não tenha lhe possibilitado mais tempo para poder colher todos os frutos e o reconhecimento que ela merecia, particularmente na arte. Suas pinturas são surpreendentes, causam um enorme impacto, e têm alto valor estético. De forma espontânea, aos poucos, sem ter visto os clássicos da pintura moderna, Socorro foi desenvolvendo linguagens próprias que têm muitas semelhanças com Chagall, Guignard, Appel, Macke, Mikhail Larionov, entre outros. Aos poucos, quando eu lhe mostrava a coincidência, ela ficava surpresa, e passou a levar para casa livros de pintura e pesquisar com avidez os estilos destes pintores. Socorro chegou a ter, ainda em vida, algum reconhecimento, tendo tido alguns trabalhos expostos em algumas exibições, algumas de caráter nacional.

Entretanto, além do caráter estético, há outras dimensões fundamentais em sua pintura. Uma delas é a capacidade de expressar essa experiência tão forte, parte da sabedoria humana ao mesmo tempo mais simples e mais profunda, de transmutar dor e sofrimento, em arte e beleza. Ela mesma escreveu a respeito de uma de suas pinturas: "pintei o meu rosto para não mostrar a minha dor. Colori minha lágrima como se fosse um pingente". Pelo seu mérito de percorrer essa experiência de vida tão difícil e essa vivência tão radical de contato mais direto com o inconsciente, e ser capaz de projetá-la de forma sublimada em sua arte, ela nos oferece uma grande oportunidade de acompanhar, com o olhar mais apropriado da contemplação artística, essa verdadeira aventura humana.

Nesta mesma direção se desdobra uma outra dimensão paralela e fundamental de sua obra, que é a riqueza expressiva e projetiva, de enorme 


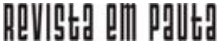

\} MARIA DO SOCORRO SANTOS - VASCONCELOS, E. M. \}

DOI: $10.12957 /$ REP.2022. 63531

riqueza simbólica e psicológica. Cada um de seus quadros é povoado pelas imagens e seres que habitavam sua imaginação e história pessoal. Era um prazer sentar com ela em torno de suas pinturas, e ouvi-la falar dos personagens de cada obra. Freud, e particularmente Jung (sem esquecer no Brasil, de sua discípula, Nise da Silveira), foram os pioneiros em nos mostrar mais sistematicamente essa capacidade humana de revelar, por meio da arte, a alma humana em toda a sua riqueza e dinâmica, expressando a singularidade de cada ser humano, e ao mesmo tempo, seu caráter universal, por comungarmos as estruturas básicas e comuns do inconsciente e do aparelho psíquico como um todo.

Talvez por isso mesmo, nos chama a atenção, do ponto de vista da reabilitação em saúde mental, como Socorro encarnava esta potencialidade da arte e da pintura como caminho e trabalho para a recuperação. Algumas vezes, ela passava fome para poder comprar um tubo de tinta que não podia faltar, e nos dizia que se fosse obrigada a parar de pintar, ela certamente voltaria a enlouquecer. Garantir esse suprimento de tintas representou um enorme desafio para ela, juntamente com os amigos que a ajudavam. Nos últimos anos de sua vida, passei a exercer também o papel discreto de amigo mecenas, que lhe repassava recursos para comprar as tintas, para que evitasse ter que passar fome. Assim, acima de tudo, Socorro deve ser conhecida por sua enorme teimosia em lutar, a despeito de todas as dificuldades, pelo seu projeto pessoal de vida e de arte, como o caminho para realizar concretamente toda a sua potência humana, e para a sua individuação. Este é o termo usado por Jung para o processo de amadurecimento psicológico para o qual todos somos chamados durante toda a vida, mas particularmente nos momentos de reelaboração psicológica e existencial diante do sofrimento mental, e que acontece de modo inexorável, de diversas formas, nas diferentes culturas e contextos sociais.

Podemos ilustrar como isso foi acontecendo para Socorro em relação à pintura, em alguns de seus próprios escritos, ao ir percebendo que teria de ir além daquilo que às vezes acontece nas oficinas convencionais de pintura:

Nunca tive um bom professor de artes que tivesse ao meu lado e entendesse os meus interesses para me ensinar pinturas. Mas antes de tomar uma iniciativa, fiz parte de várias oficinas. Ao longo do tempo passei a perceber que nada adiantava, pois se o que eu queria mesmo era fazer um trabalho, no qual fosse levada a sério.

Mas quando ia tomar uma iniciativa, não podia. Por um simples pretexto, no qual os usuários só podem fazer pintura como se fosse apenas um tratamento. Mas eu nunca fiz nenhuma pintura como um tratamento, também nunca aceitei como uma loucura. Você quer ver alguém viajar no tempo: é quando se vê os pássaros voar, as árvores oferecendo uma sombra, os animais correndo nas florestas, vê-los todos convidando para nos mostrar 


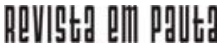

\} MARIA DO SOCORRO SANTOS - VASCONCELOS, E. M. \}

DOI: 10.12957/REP.2022. 63531

como é bom ver o sol nascer e as árvores florir, enfeitando com as cores e a beleza de cada amanhecer do dia.

Quando se percorre esse caminho, a sensação da conquista é inconfundível. Ela mesma descreve essa experiência:

Não devemos abrir mão daquilo que mais gostamos de fazer, seja o que for. Ao passar pelos sonhos mais difíceis, não devemos desistir de nada. Pois acredito muito no que cada um de nós escolheu para fazer e ter prazer, sem que nada nos impeça, não importa a idade. Não sei se posso chamar de terapia, mas uma coisa eu garanto: fazer um trabalho que a gente gosta é como se estivesse realizando cada minuto dos seus momentos mais felizes. Pois é assim que me sinto em cada uma das pinturas que faço.

Para aqueles que gostariam de conhecer Socorro falando sobre sua experiência de vida, a TV Pinel, um projeto belíssimo de comunicação alternativa do Núcleo de Intervenção Cultural do Instituto Municipal Philippe Pinel, no Rio de Janeiro, produziu um vídeo intitulado Habitante de Lugar Nenhum, disponível no Youtube bastando apenas colocar lá o título. O vídeo contém depoimentos dela e de várias outras lideranças de usuárias(os) ativas(os) na época, gravados por volta dos anos 1999 e 2000. O pequeno vídeo/documentário finaliza exatamente com Socorro cantando uma bela canção nas areias de uma praia. Alem disso, entre as imagens que colocamos após este texto, inserimos em primeiro lugar uma foto da Socorro, tirada provavelmente no Fórum Social Global em Porto Alegre, em janeiro de 2005. Nos eventos do campo social e particularmente da saúde mental, ela vendia suas obras assim. Estendia um pano no chão, expunha suas pinturas, e as vendia muito barato para o nosso público, que sabemos não poder pagar muito. Neste período, sugerimos a ela que vendesse apenas cópias de seus trabalhos, para mantê-los consigo. Ela gostou da ideia, pesquisou as alternativas e conseguiu fazer cópias coloridas de boa qualidade, impressas em papel couchê, e começou assim a vendê-las, mantendo os originais.

Infelizmente, no auge deste momento tão importante de sua carreira, em 5 de março de 2005, aos 52 anos, Socorro nos deixou, vítima de um enfarte do coração. Ele tinha uma cardiopatia que Ihe exigia cuidados regulares, sobre os quais pouco falava, e as dificuldades de acesso a serviços e exames especializados de cardiologia no SUS acabaram levando-a a postergar as consultas. Casos de usuárias(os) da saúde mental como o da Socorro infelizmente não são raros, e merecem toda a nossa atenção. À medida que vão gradualmente se empoderando, os serviços e nós profissionais de saúde mental tendemos a descuidar deste suporte sempre necessário a elas(es) na área da saúde em geral...

Depois de sua passagem, nós, seus amigos mais próximos do Instituto Franco Basaglia e do Projeto Transversões, assumimos o trabalho de 


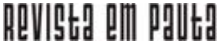

\} MARIA DO SOCORRO SANTOS - VASCONCELOS, E. M. \}

DOI: 10.12957/REP.2022.63531

guardar e divulgar sua obra, tomando a responsabilidade de gerir os direitos autorais, realizar algumas mostras de suas pinturas, estimular a adoção de seu nome para o CAPS III da Rocinha, uma das maiores e mais desafiantes favelas da cidade do Rio de Janeiro. E temos também promovido a divulgação de sua obra em capas de livros, periódicos locais e nacionais, e cartazes de eventos da luta antimanicomial e do campo da saúde mental. Com o término mais definitivo das atividades do IFB, estamos negociando a posse e preservação das obras da Socorro com um dos museus especializados do campo, mas com o compromisso de ter acesso digital e o direito de uso de suas imagens, como responsabilidade com a divulgação de sua memória e sua pintura, pois ela inspira e continuará a inspirar muitos outros, por muitas razões.

Inicialmente, porque ela toca profundamente a cada um de nós, militantes antimanicomiais, pois o exemplo de vida e a obra de Socorro representam objetivos importantes do que buscamos com a nossa luta. Primeiro, para podermos aprender com alguém que falava 'de dentro', das sutilezas do processo de recuperação, para nos ensinar a estimular melhor cada pessoa a se escutar e definir seus projetos de vida, e com isso, poder ir conquistando atividades e trabalhos que expressem seus anseios mais profundos e sua singularidade. E isso, sem desconhecermos a condição existencial diferenciada colocada pelo sofrimento mental, para que cada um(a) possa alcançar o máximo de autoestima e reconhecimento social a que tem direito, como pessoa humana, e por seus trabalhos e suas contribuições à sociedade. Segundo, para fomentar nos serviços de saúde mental e nos ambientes sociais e institucionais a solidariedade humana, o empoderamento pessoal e coletivo, a participação e o protagonismo, a defesa dos direitos, e a luta por uma sociedade mais igualitária e justa.

Além deles, o exemplo de sua história e a beleza de sua obra certamente inspiram principalmente seus pares de condição existencial e subjetiva, particularmente aquelas(es) que estão se iniciando neste caminho tão desafiador de enfrentar ao mesmo tempo a opressão e a discriminação social, de gênero e racial, a dor da presença transbordante do inconsciente, o estigma, as dificuldades da assistência em saúde mental, e mesmo assim, terem esperança e serem capazes de construir, à sua maneira, um projeto singular, rico e engajado de vida, trabalho e de lutas.

\section{As muitas linguagens na obra de Maria do Socorro Santos}

Socorro investiu na pintura durante um período muito longo de sua vida, em oficinas de serviços de saúde mental. Contudo, foi particularmente nos últimos cinco anos de sua vida, de 2000 a 2005, que a pintura passou a representar a atividade de que mais gostava, demonstrando um profundo prazer em realizá-la, e sua obra ganhou assim maior densidade 
artística. Neste período, pintou freneticamente, mostrando uma incrível capacidade de se expressar em variados estilos. Um olhar sobre o conjunto de seus trabalhos nos permite identificar algumas linguagens que se mostraram mais maduras do ponto de vista das soluções técnicas, da liberdade de experimentação e valor estético, e da expressão da riqueza de seu universo interior, que serão exemplificadas na presente mostra.

Socorro não dava título à maioria de seus quadros. No entanto, em quase todas as séries descritas abaixo, havia pelo menos um quadro com nome, e daí resolvemos então dar este nome, no plural, a toda a respectiva série. Os leitores poderão facilmente identificar os "tipos ideais" de cada linguagem, pelas suas características diferenciadas, apresentadas na mesma ordem que descrevemos a seguir, mas devem notar que particularmente entre a primeira e a segunda séries, temos várias obras de transição, que misturam características das duas linguagens.

\section{A série "Lugares Secretos"}

Nesta série, havia apenas um quadro com nome, intitulado "Lugar Secreto". Resolvemos então dar este nome, no plural, a toda a série.

Neste conjunto, Socorro dá asas às suas e às nossas fantasias, fazendo voar seres imaginários sobre painéis florais combinados com fundos de cores fortes, geralmente em azul, vermelho e, ou amarelo, com efeitos simbólicos importantes. Para quem se dispunha a sentar junto com ela contemplando estes quadros, ela contava estórias com vários destes seres, ou se perguntava, admirada de si mesma, qual o possível significado, por exemplo, de uma ave fundida no corpo de uma mulher, que saiu de seus pincéis sem ela perceber muito bem.

Embora não conhecesse os clássicos da pintura universal, esta linguagem de Socorro lembra um pouco a obra de Guignard e Chagall, embora com elementos próprios que fazem a sua marca e a sua singularidade. Um deles, diferentemente de Chagall, está na transparência e no inacabamento que dá ao corpo destes seres, acentuando o seu caráter surrealista e talvez querendo enfatizar a sua qualidade de seres etéreos, próprio do universo de uma imaginação ainda em pleno processo criativo. Assim, além da enorme beleza estética, esta série marca uma profunda capacidade expressiva e projetiva, com um largo impacto no campo da saúde mental.

No fundo dos quadros, Socorro utiliza técnicas pictóricas predominantemente impressionistas, constituindo painéis quase planos, com apenas um leve toque de profundidade e perspectiva. Entretanto, o que nos chama mais a atenção é sua habilidade alquímica com a mistura de tons, já que utiliza largamente de cores saturadas, conseguindo alcançar um raro equilíbrio cromático. 
Contudo, muito além de suas qualidades formais, nesta série, Socorro nos convida a viajar com ela, a penetrar nestes lugares secretos de nossos sonhos e fantasias, e aprender inclusive a reconhecer os seres que lá habitam. Nesta aventura, ela nos chama para exercitar nossos anseios mais íntimos de individuação, tão importante para o amadurecimento psicológico de qualquer ser humano. É tendo a oportunidade de conviver com esses 'estrangeiros' dentro de nós, que somos convidados a uma aventura pessoal profunda, com muitas implicações e mudanças na vida concreta, e que também estimula a aceitação e o convívio com a diversidade e o diferente na vida social, elemento fundamental para essa frente que abraçamos junto com Socorro, a luta antimanicomial.

\title{
A série "Mundo cão: os rejeitados"
}

Na medida em que Socorro investia na linguagem desenvolvida na série "Lugares Secretos", nos anos 2004/2005, foi surgindo, também gradualmente, um outro estilo, que no início ainda conviveu e manteve os fundos florais impressionistas. Entretanto, agora seus personagens parecem abandonar parcialmente o mundo etéreo, ganhando uma maior concretude, uma corporeidade não translúcida, mas finita, bem delimitada, com cores próprias, fortes, saturadas, e na maioria deles, homogêneas, em uma linguagem e composição muita assemelhada aos mosaicos.

Apesar da maior concretude, estes inúmeros seres que emergem dos pincéis de sua imaginação, e que vão tomando sorrateiramente quase todo o espaço de seus quadros, não são menos surrealistas, disformes e estranhos. Mas o que talvez mais impressione é que parecem interagir, conversar entre si, tocar uns aos outros.

Podemos talvez tentar penetrar nos segredos de Socorro nesta série pelos títulos que ela deu aos trabalhos. Três dos quadros deste conjunto receberam títulos: "Mundo cão"; "Os rejeitados", e "Amor e ódio". Decidimos manter os dois primeiros nomes para a série, talvez porque o ódio e a opressão tenham sim gerado este mundo cão e os rejeitados, como ela própria o fora durante a maior parte de sua vida.

No entanto, o que foi raríssimo, Socorro escreveu um curto poema sobre "Os rejeitados", que revela mais precisamente sua relação com essas imagens:

\section{OS REJEITADOS}

\author{
NÃO SEI QUE HISTÓRIA É ESTA \\ NEM O QUE EU VOU DIZER. \\ Uns se abraçando de lado e outros de cara a torcer. \\ Outros juntos cochichando algo que eles vão fazer.
}


É melhor ficar olhando o que vai acontecer...

Olha só que engraçado, o pássaro ali a olhar como quem está dizendo: "Vou logo me preparar".

Coisas boas eu não sei - vou procurar meu lugar.

Esse breve poema, que encontramos mais recentemente, deixa mais claro e nos reativa mais vivamente o que lembramos das conversas com ela. As imagens que criava funcionavam quase como cenas teatrais abertas ao improviso, a partir das quais ela imaginava estórias entre as(os) personagens e seres representados, sempre com finíssimo humor, e com as quais se divertia muito consigo mesma! Morava sozinha, e quando não acolhia lá outras(os) usuárias(os) em necessidade, ela enchia sua casa com essa convivência imaginária!

\section{A série "Os Esquecidos"}

Talvez esta seja a última linguagem desenvolvida por Socorro, com poucos quadros, pintados já em 2005. Em relação às séries anteriores, o fundo vai perdendo aos poucos seu floral e suas cores alegres, se escurece, e do negro circundante emergem seres delineados em branco, em claro contraste com os tons noturnos do contexto. Como na série "Lugares Secretos", os personagens são também translúcidos, etéreos, mas agora parecem ter saído muito mais de pesadelos do que de sonhos e fantasias. Estes seres são muito mais fantasmagóricos, e alguns chegam a esboçar linhas e detalhes em vermelho saturado, cor de carne e sangue vivos.

Sem dúvida alguma, estes quadros são mais difíceis de serem contemplados por olhos desavisados. Talvez aqui tenha emergido nos pincéis de Socorro os ecos mais sombrios de Hieronymus Bosch, o enigmático pintor holandês do século XV, ou do mais recente, catalão, Salvador Dali, não propriamente em suas linguagens formalmente clássicas, mas no espírito surrealista mais genuíno e profundo, de tentar aprisionar na tela as imagens originais dos seres mais assustadores do inconsciente. Assim, esta série tem não só um valor artístico próprio, mas sobretudo uma enorme importância expressiva e projetiva.

\section{A série em Papel Artesanal}

Nesta série, produzida nos anos de 2001 e 2002, Socorro também investiu na produção de papéis artesanais, que faziam sobressair a textura. A irregularidade da superfície fez gerar um efeito de descontinuidade no uso do pincel, como recurso estilístico singular. Sobre esta superfície diferenciada, Socorro pintava predominantemente temas mais abstratos, de 


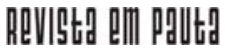

\} MARIA DO SOCORRO SANTOS - VASCONCELOS, E. M. \}

DOI: 10.12957/REP.2022.63531

fortes efeitos decorativos, apesar de que seu estilo surrealista não se manteve completamente ausente: aqui ou ali, pequenos rostos humanos ou pássaros se fazem aparecer de forma mais ou menos furtiva.

Nenhum dos quadros recebeu títulos, e nos abstemos de criar um nome artificial, optando por chamar a série pela particularidade do meio utilizado.

\section{$\mathrm{XXX}$}

Não tenho dúvida, o espírito da Socorro está vivo, se encontra entre nós, através de suas obras e das lembranças dos numerosos bons momentos de convivência com ela. No entanto, sempre que retomo essas recordações, a saudade fica mais forte, e talvez o melhor jeito que encontrei para lidar com ela, é ir escrevendo e burilando estas linhas...

Rio de Janeiro, outubro de 2021.

DOI: 10.12957/rep.2022. 63531

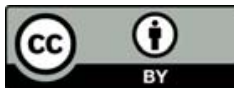

A Revista Em Pauta: Teoria Social e Realidade Contemporânea está licenciada com uma Licença Creative Commons Atribuição 4.0 Internacional. 


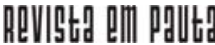

\} MARIA DO SOCORRO SANTOS - VASCONCELOS, E. M. \}

DOI: 10.12957/REP.2022. 63531

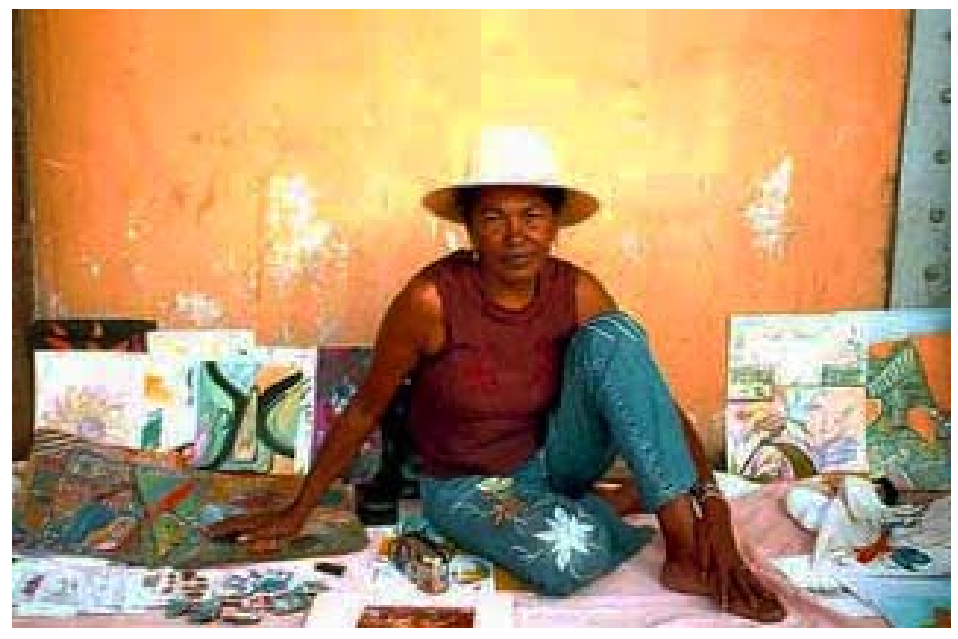




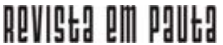

\} MARIA DO SOCORRO SANTOS - VASCONCELOS, E. M. \}

DOI: 10.12957/REP.2022. 63531

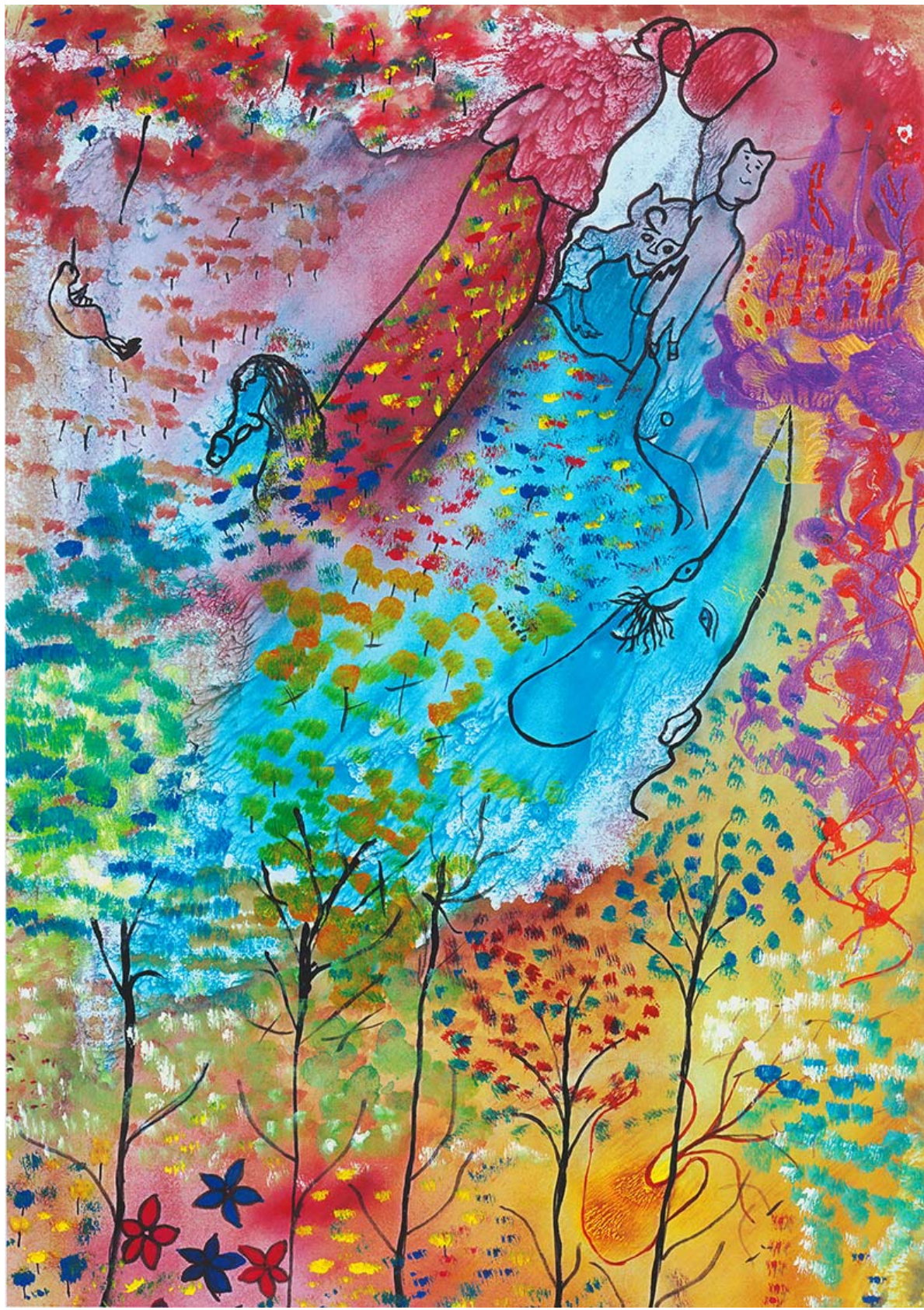

EM PAUTA, Rio de Janeiro - $1^{\circ}$ Semestre de 2022 - n. 49, v. 20, p. 270 - 299

Revista da Faculdade de Serviço Social da Universidade do Estado do Rio de Janeiro 


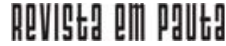

\} MARIA DO SOCORRO SANTOS - VASCONCELOS, E. M. \}

DOI: 10.12957/REP.2022. 63531

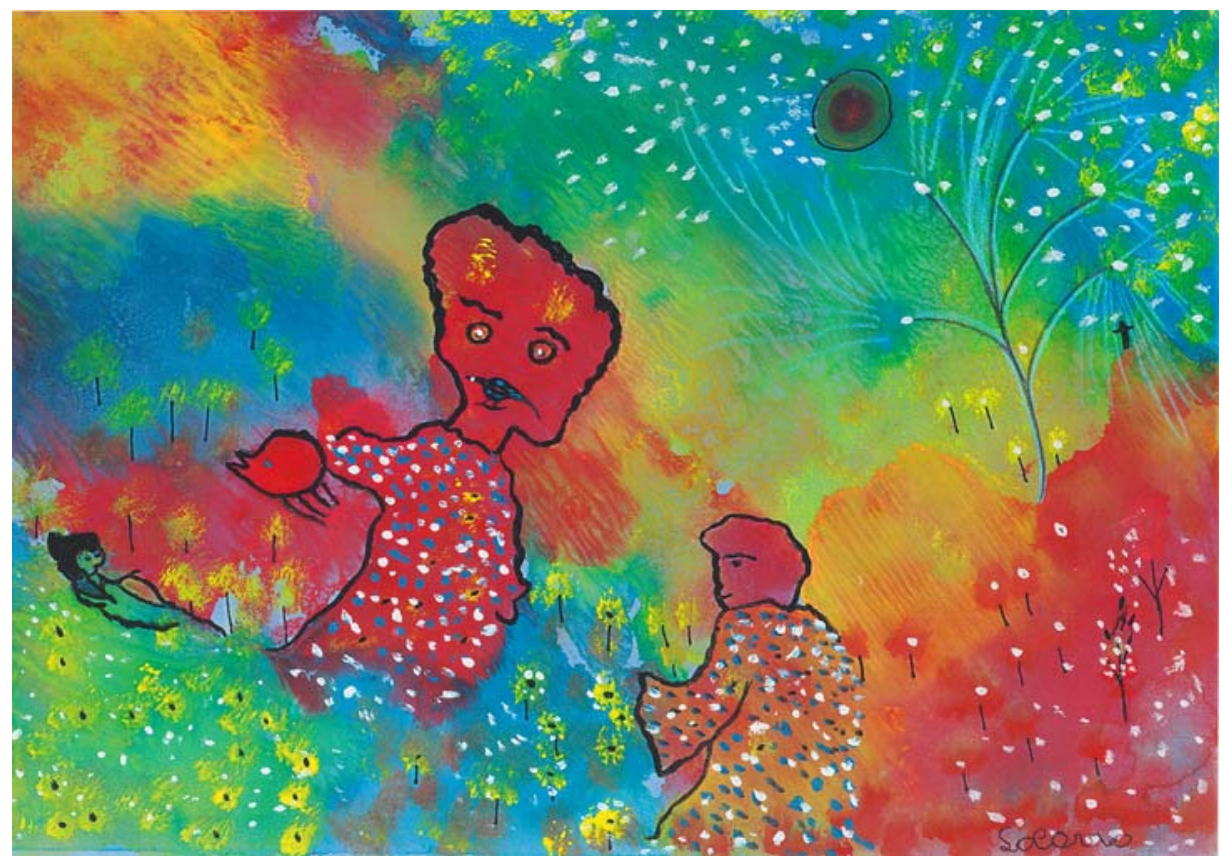




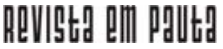

\} MARIA DO SOCORRO SANTOS - VASCONCELOS, E. M. \}

DOI: 10.12957/REP.2022. 63531

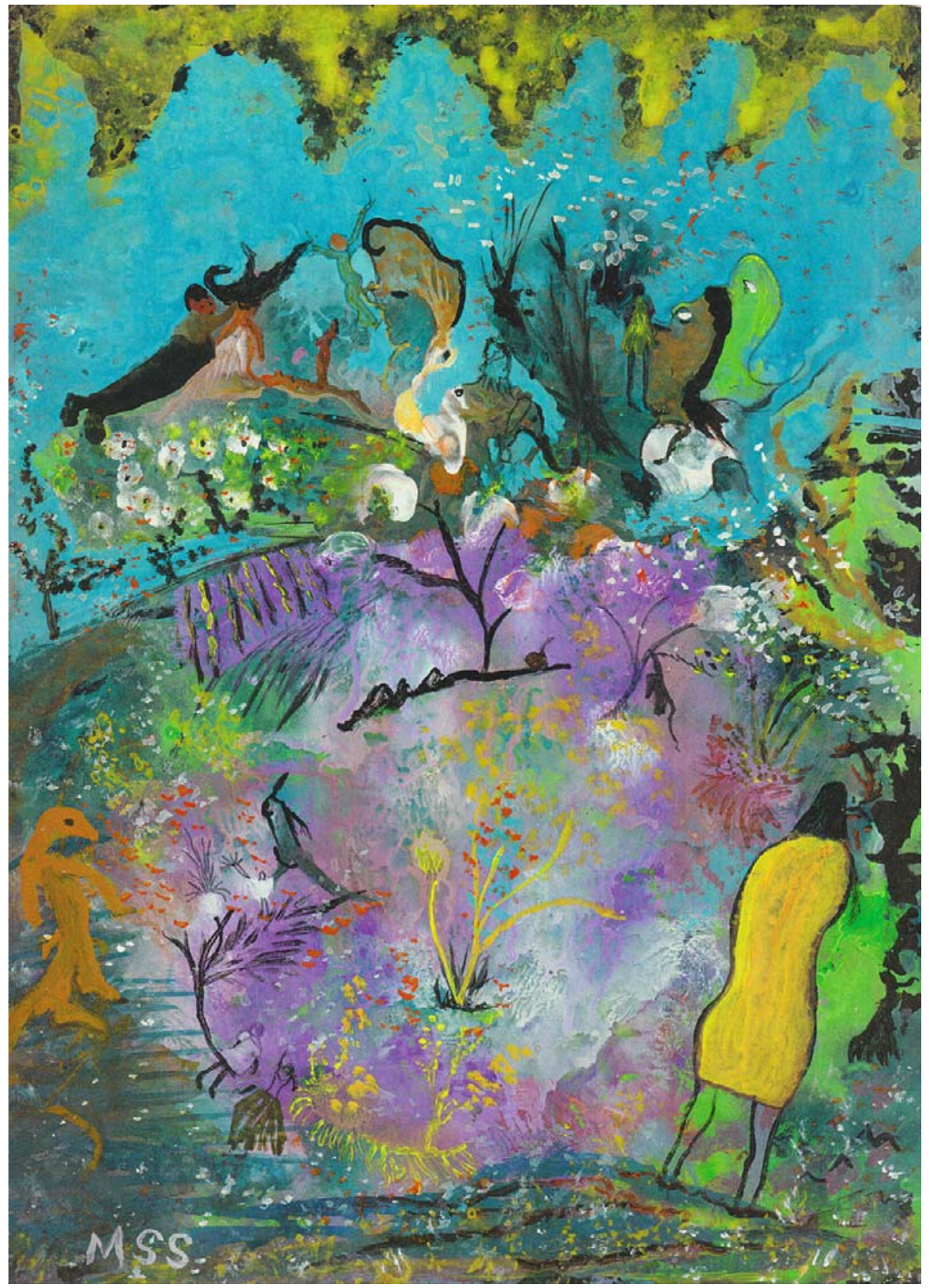

EM PAUTA, Rio de Janeiro - $1^{\circ}$ Semestre de 2022 - n. 49, v. 20, p. 270 - 299

Revista da Faculdade de Serviço Social da Universidade do Estado do Rio de Janeiro 


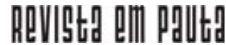

\} MARIA DO SOCORRO SANTOS - VASCONCELOS, E. M. \}

DOI: 10.12957/REP.2022.63531

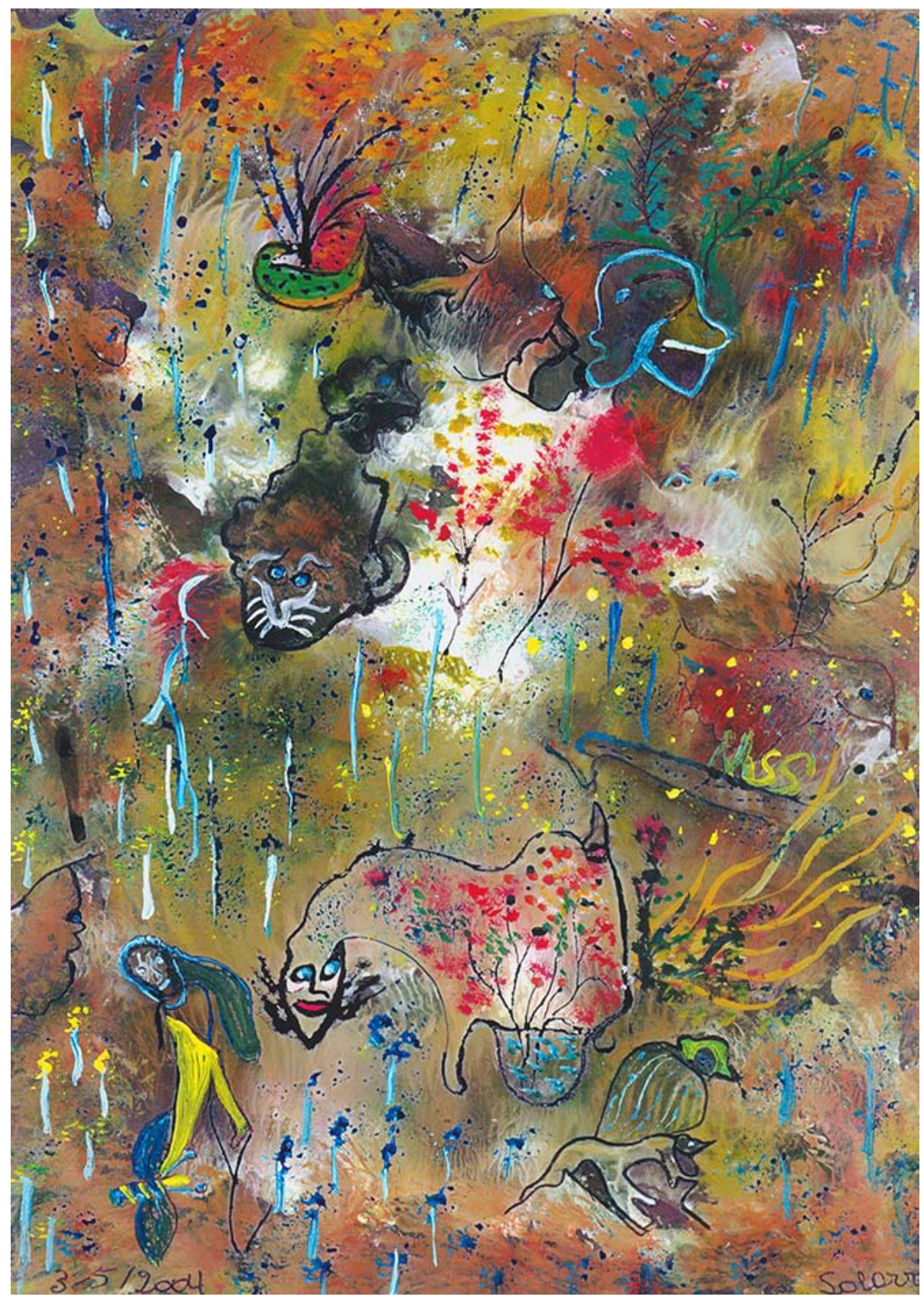




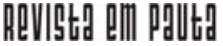

\} MARIA DO SOCORRO SANTOS - VASCONCELOS, E. M. \}

DOI: 10.12957/REP.2022. 63531

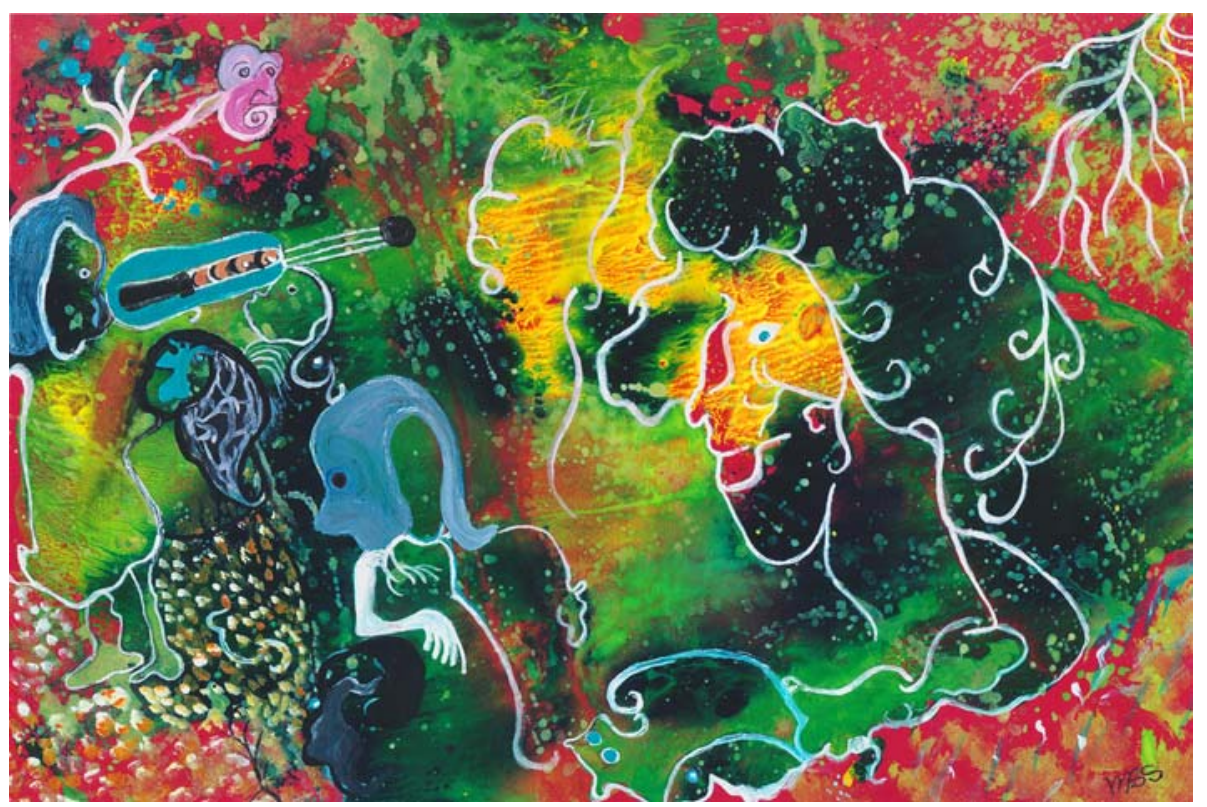




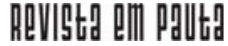

\} MARIA DO SOCORRO SANTOS - VASCONCELOS, E. M. \}

DOI: 10.12957/REP.2022.63531

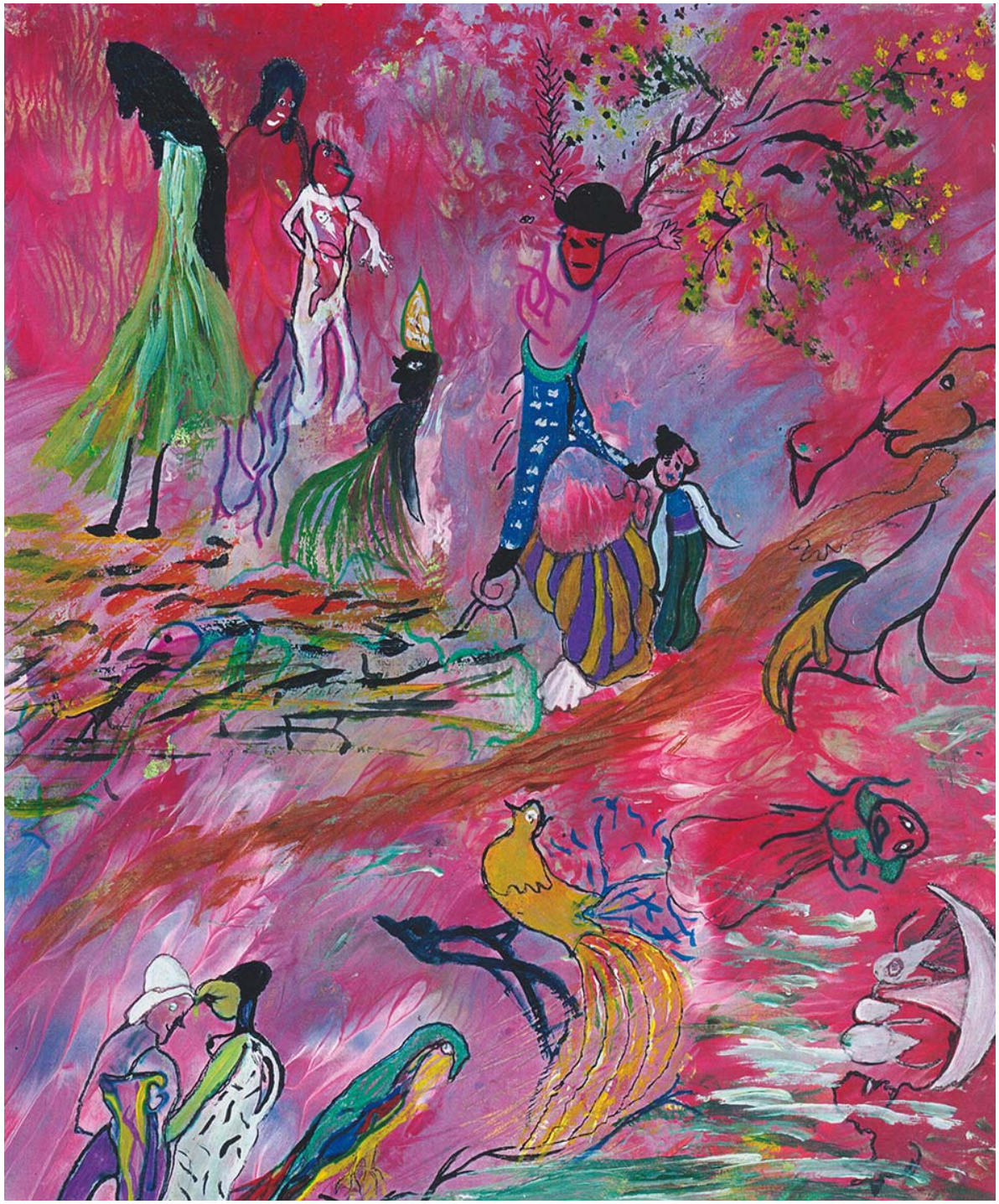




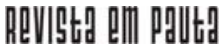

\} MARIA DO SOCORRO SANTOS - VASCONCELOS, E. M. \}

DOI: 10.12957/REP.2022. 63531

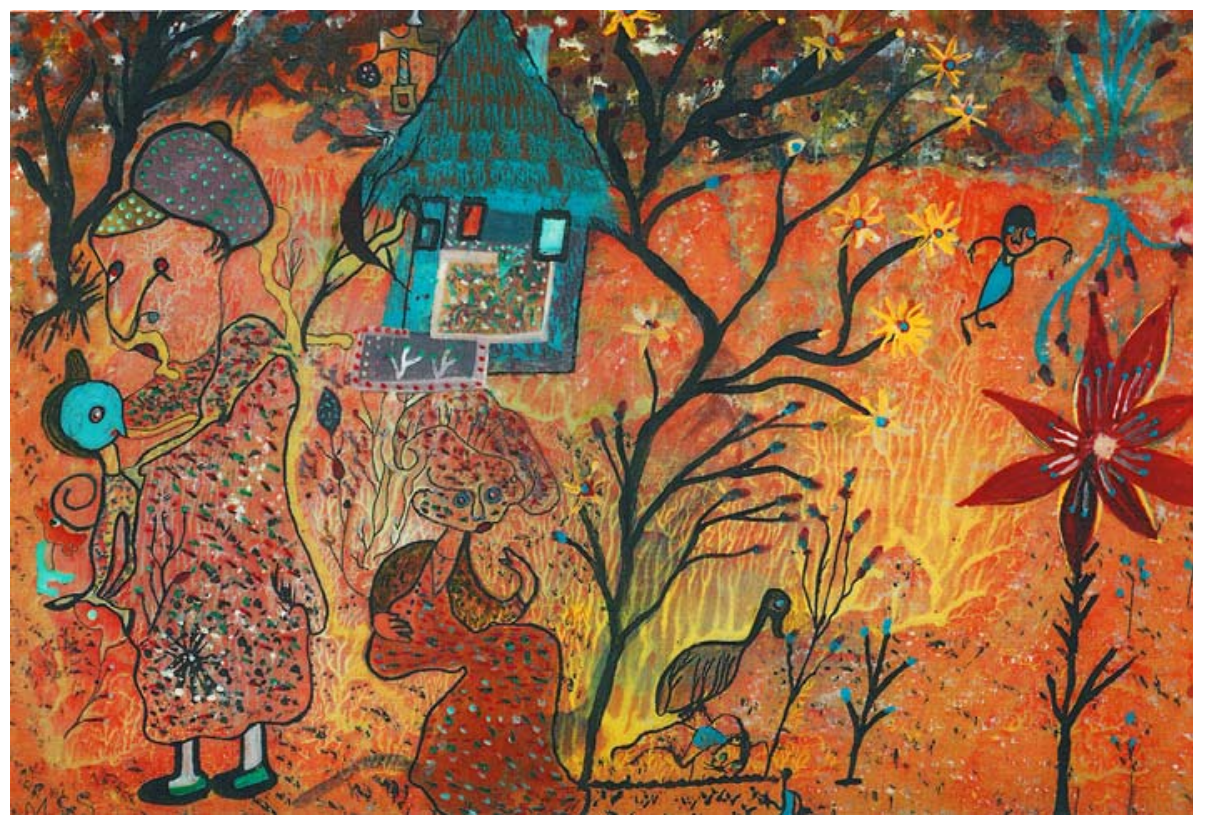




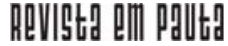

\{ MARIA DO SOCORRO SANTOS - VASCONCELOS, E. M. \}

DOI: 10.12957/REP.2022. 63531

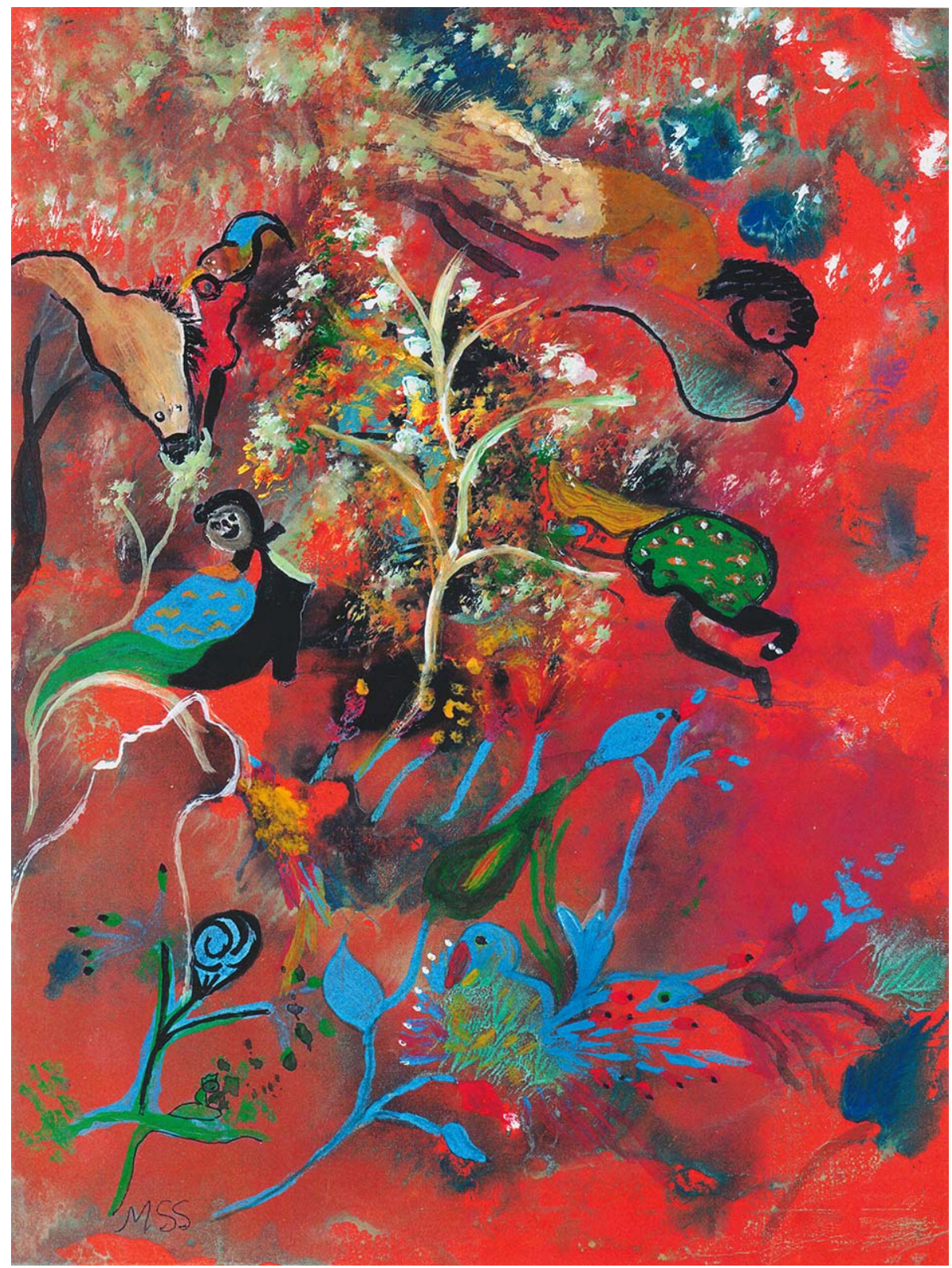




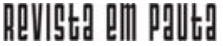

\} MARIA DO SOCORRO SANTOS - VASCONCELOS, E. M. \}

DOI: 10.12957/REP.2022. 63531

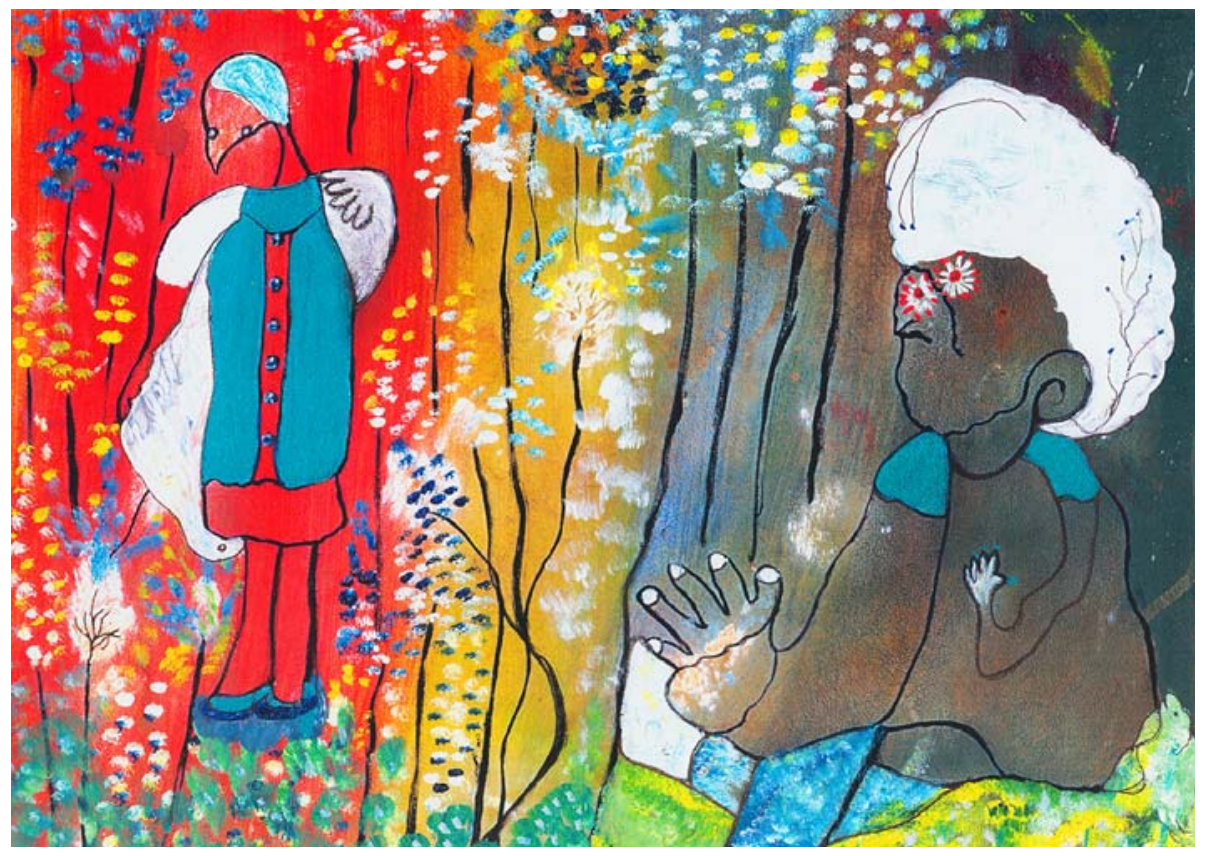




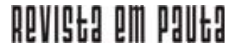

\{ MARIA DO SOCORRO SANTOS - VASCONCELOS, E. M. \}

DOI: 10.12957/REP.2022. 63531

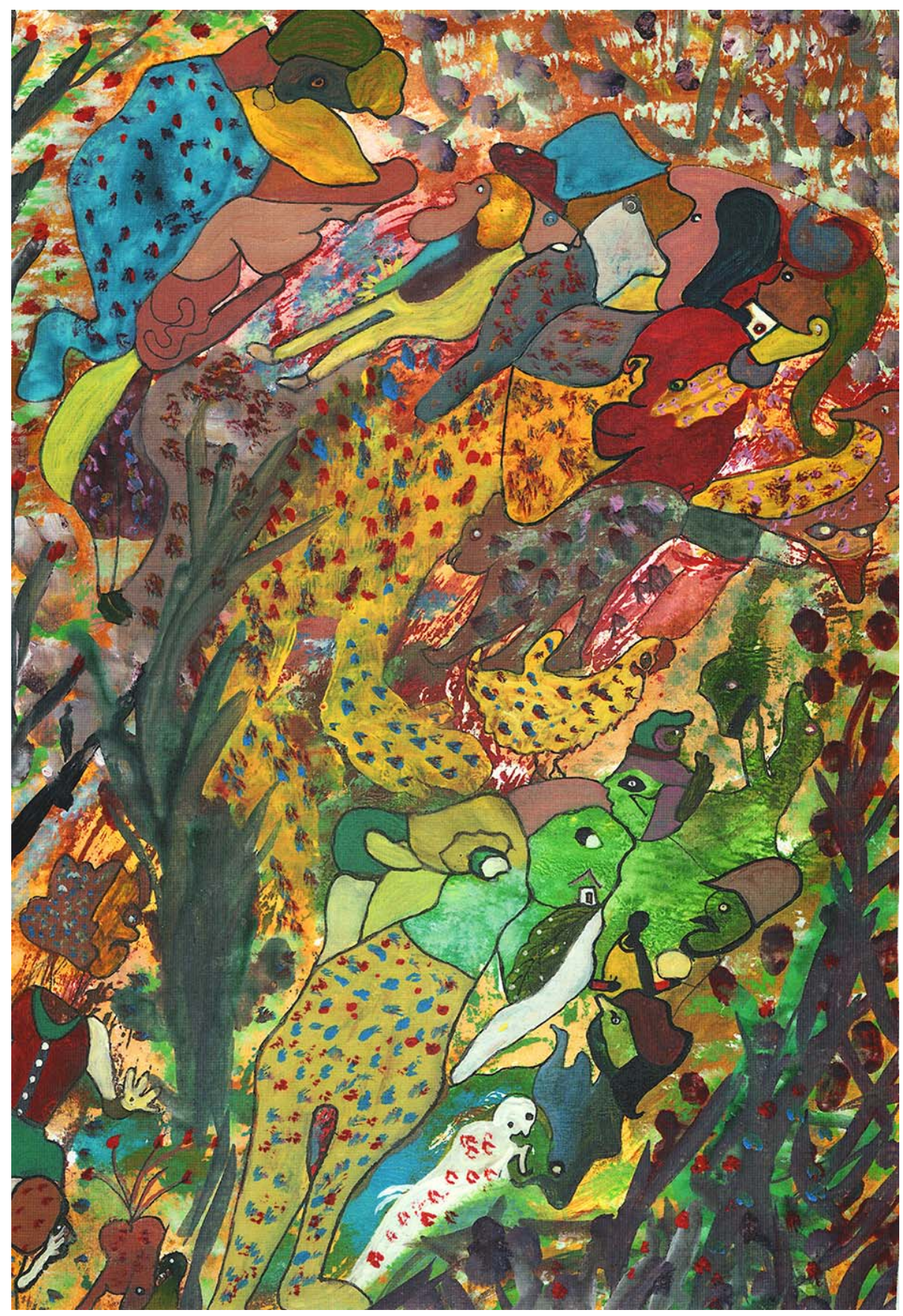




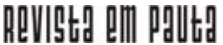

\} MARIA DO SOCORRO SANTOS - VASCONCELOS, E. M. \} DOI: 10.12957/REP.2022. 63531

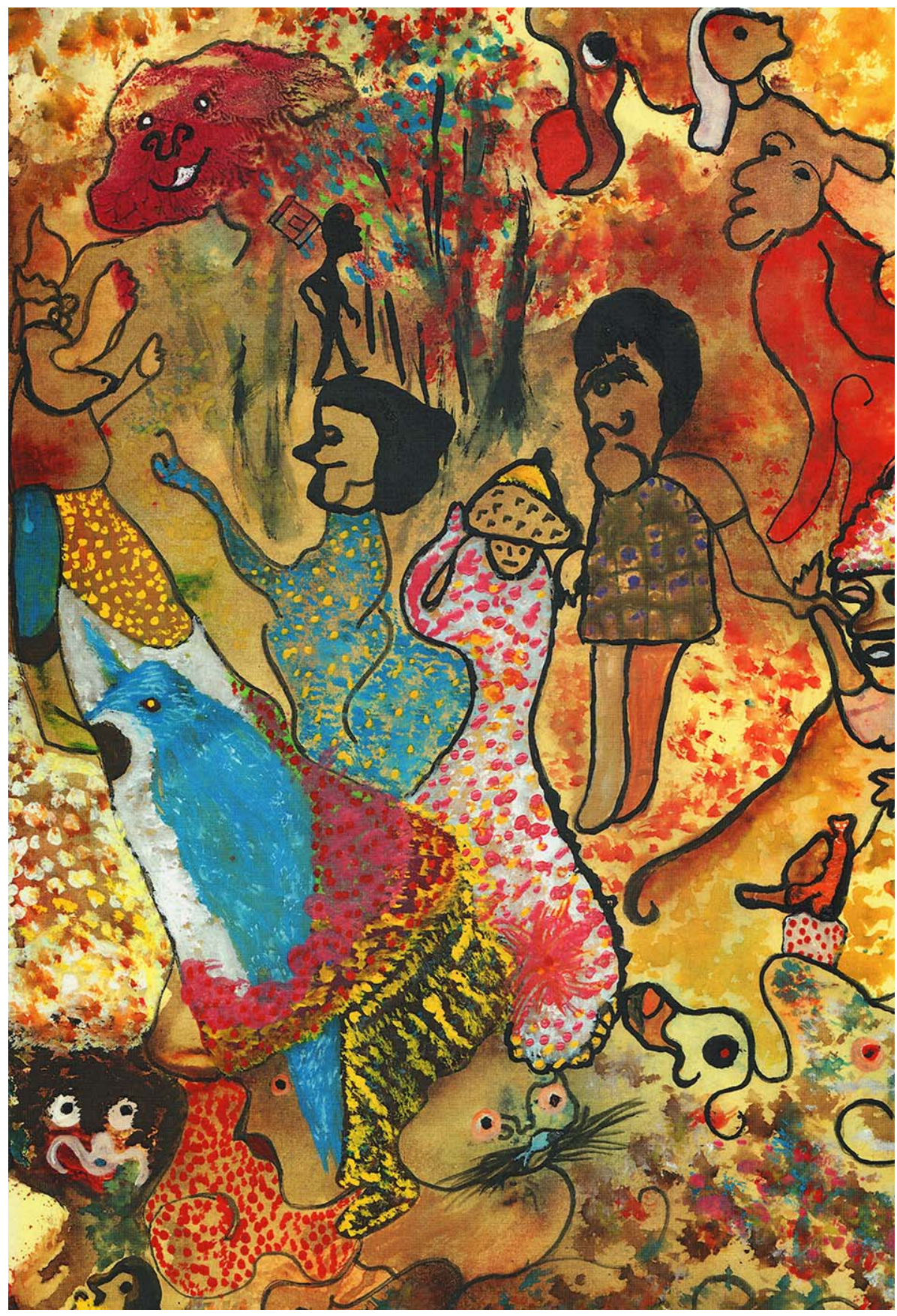

EM PAUTA, Rio de Janeiro - $1^{\circ}$ Semestre de 2022 - n. 49, v. 20, p. 270 - 299 


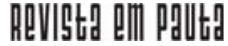

\} MARIA DO SOCORRO SANTOS - VASCONCELOS, E. M. \}

DOI: 10.12957/REP.2022. 63531

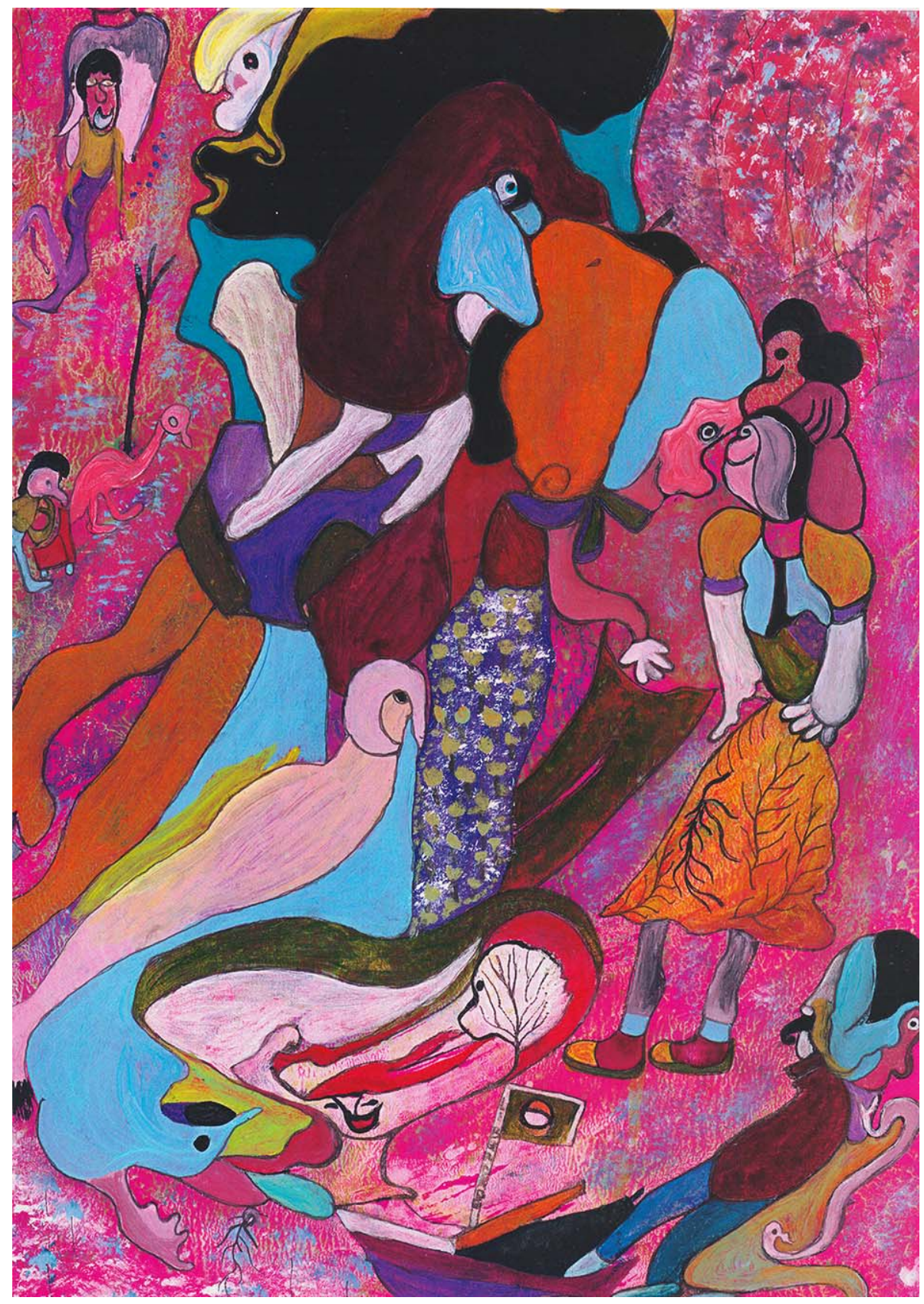




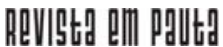

\} MARIA DO SOCORRO SANTOS - VASCONCELOS, E. M. \}

DOI: 10.12957/REP.2022.63531

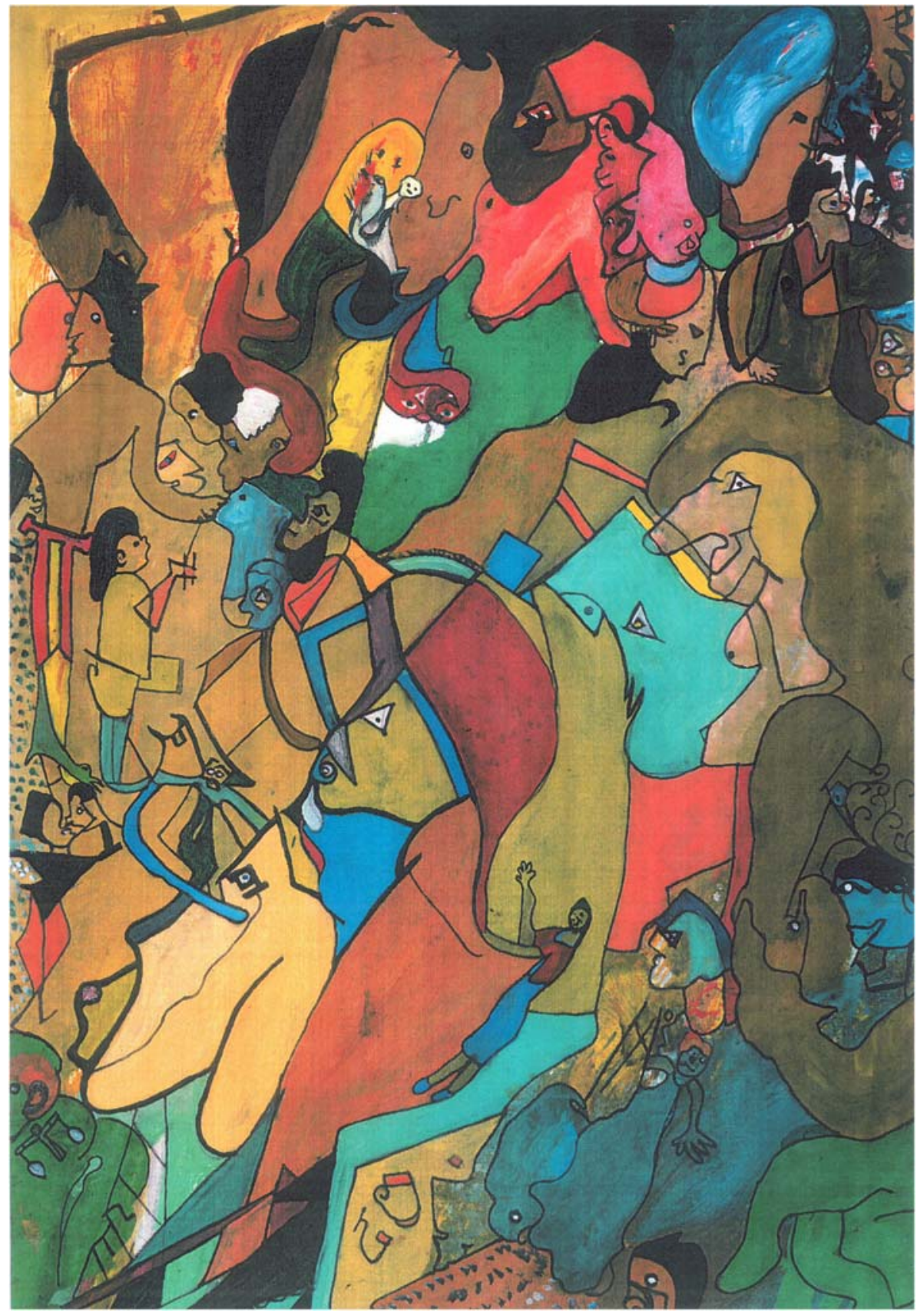

EM PAUTA, Rio de Janeiro - $1^{\circ}$ Semestre de 2022 - n. 49, v. 20, p. 270 - 299

Revista da Faculdade de Serviço Social da Universidade do Estado do Rio de Janeiro 


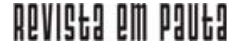

\} MARIA DO SOCORRO SANTOS - VASCONCELOS, E. M. \}

DOI: 10.12957/REP.2022. 63531

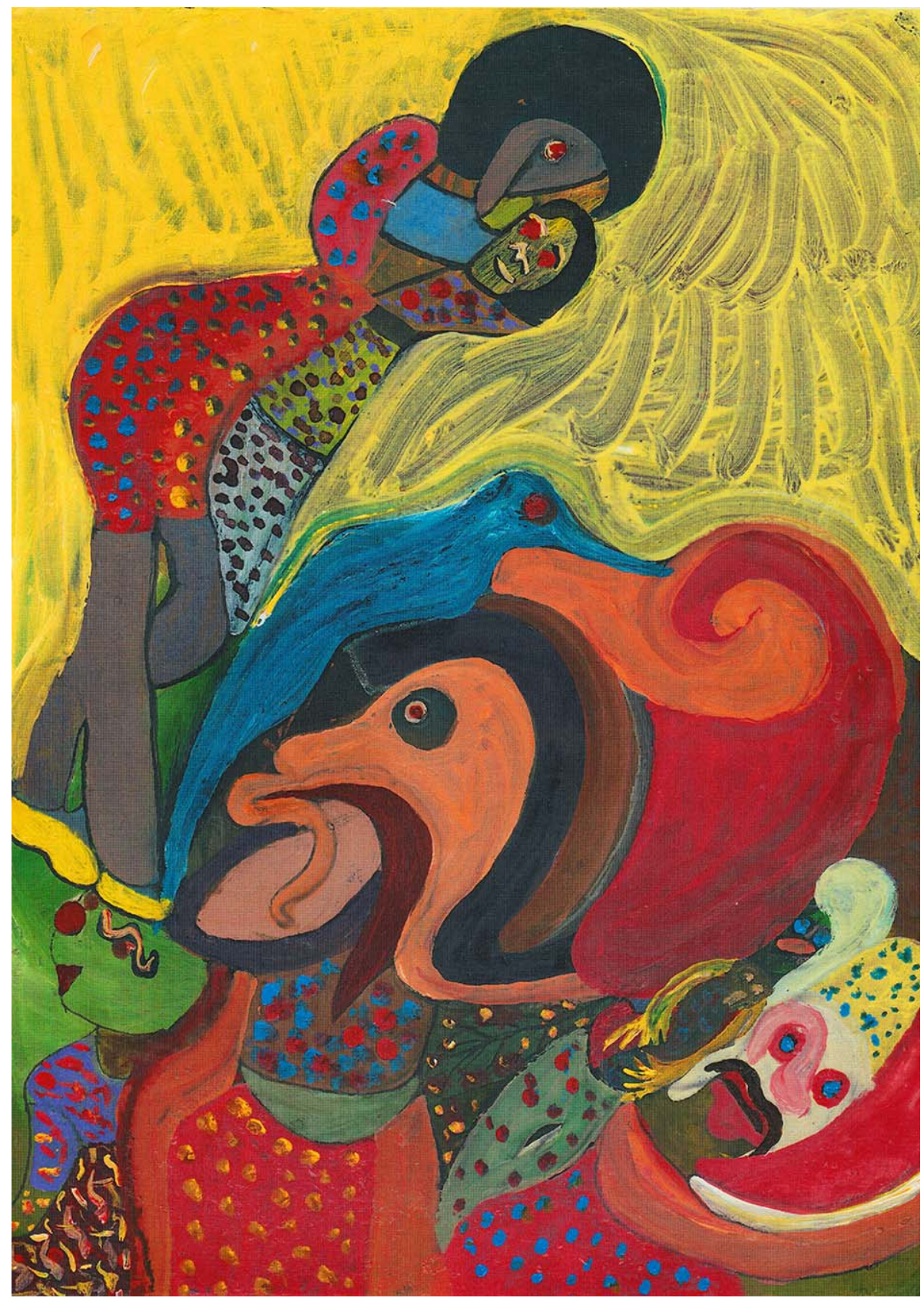




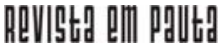

\} MARIA DO SOCORRO SANTOS - VASCONCELOS, E. M. \}

DOI: 10.12957/REP.2022. 63531

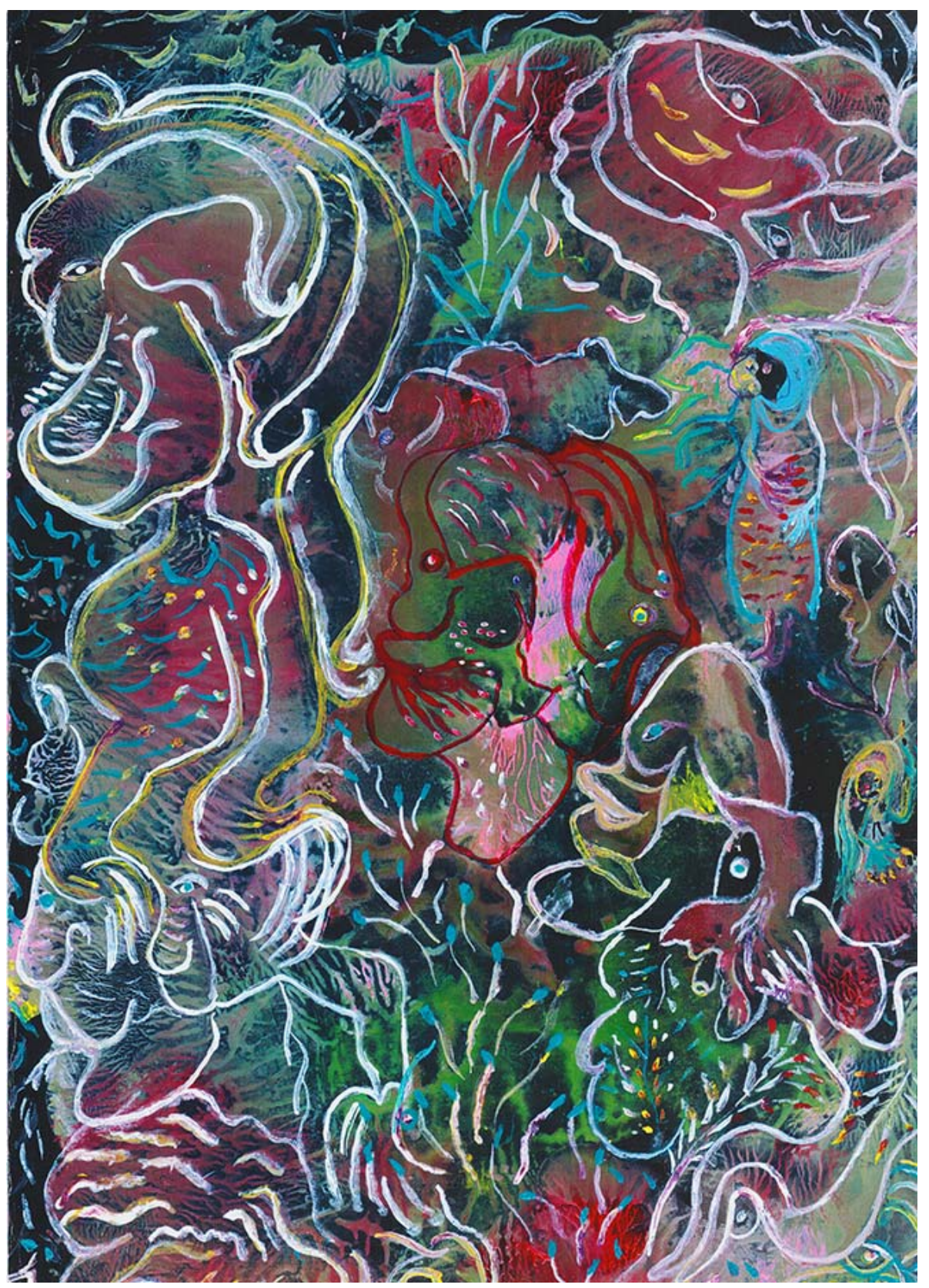

EM PAUTA, Rio de Janeiro - $1^{\circ}$ Semestre de 2022 - n. 49, v. 20, p. 270 - 299 


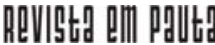

\{ MARIA DO SOCORRO SANTOS - VASCONCELOS, E. M. \}

DOI: 10.12957/REP.2022.63531

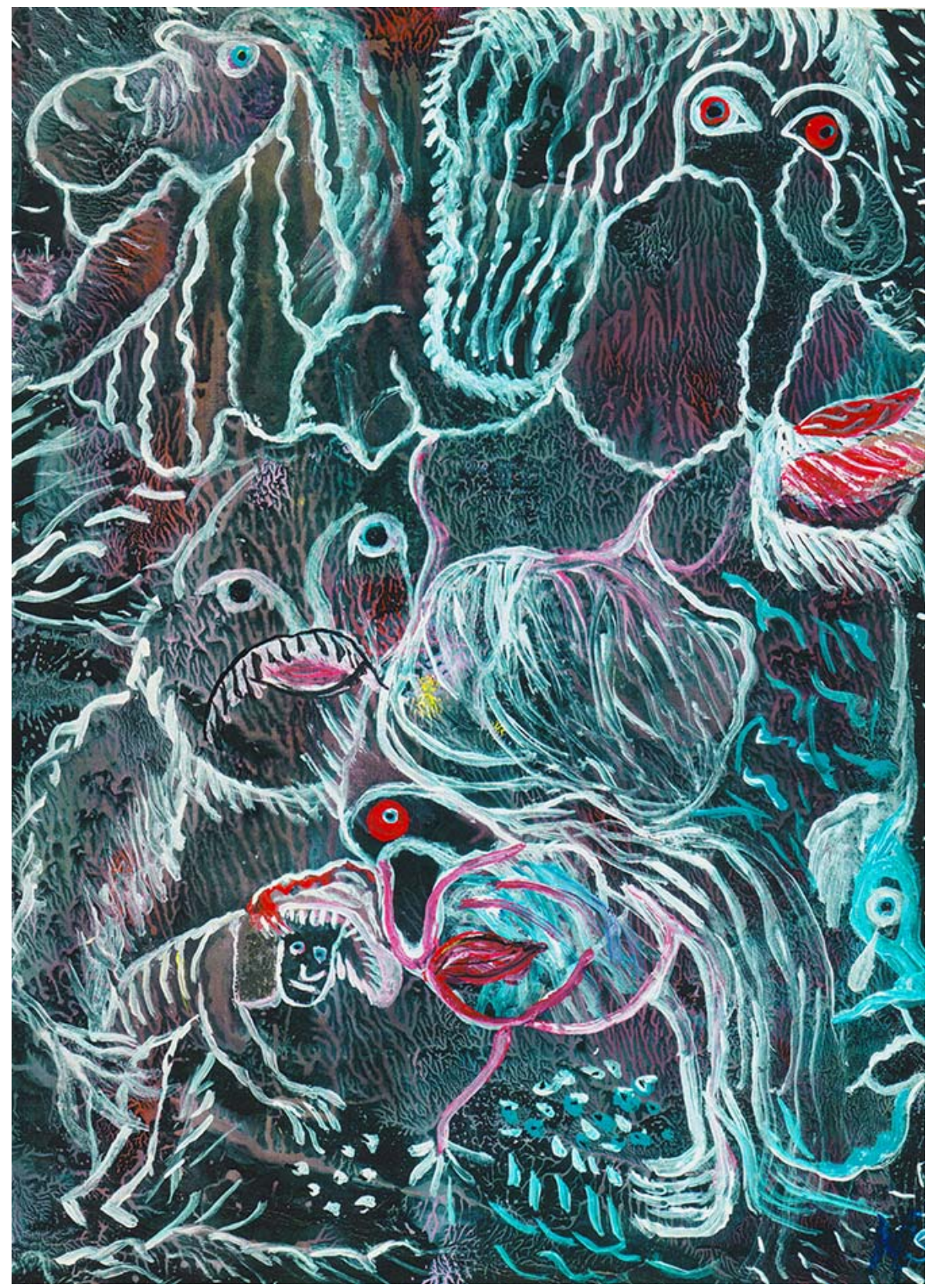




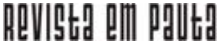

\} MARIA DO SOCORRO SANTOS - VASCONCELOS, E. M. \}

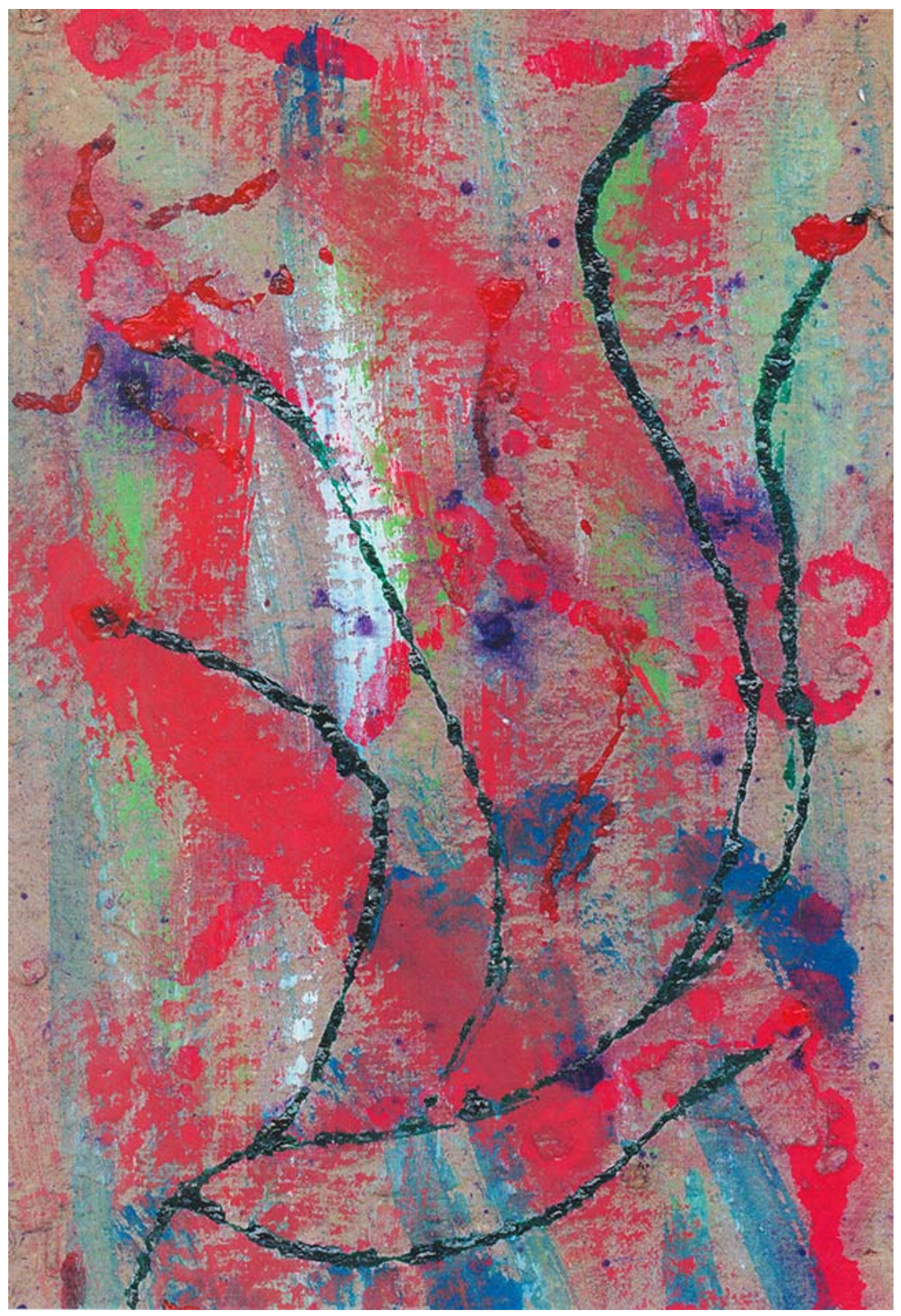

EM PAUTA, Rio de Janeiro - $1^{\circ}$ Semestre de 2022 - n. 49, v. 20, p. 270 - 299 


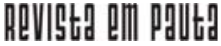

\} MARIA DO SOCORRO SANTOS - VASCONCELOS, E. M. \}

DOI: 10.12957/REP.2022.63531

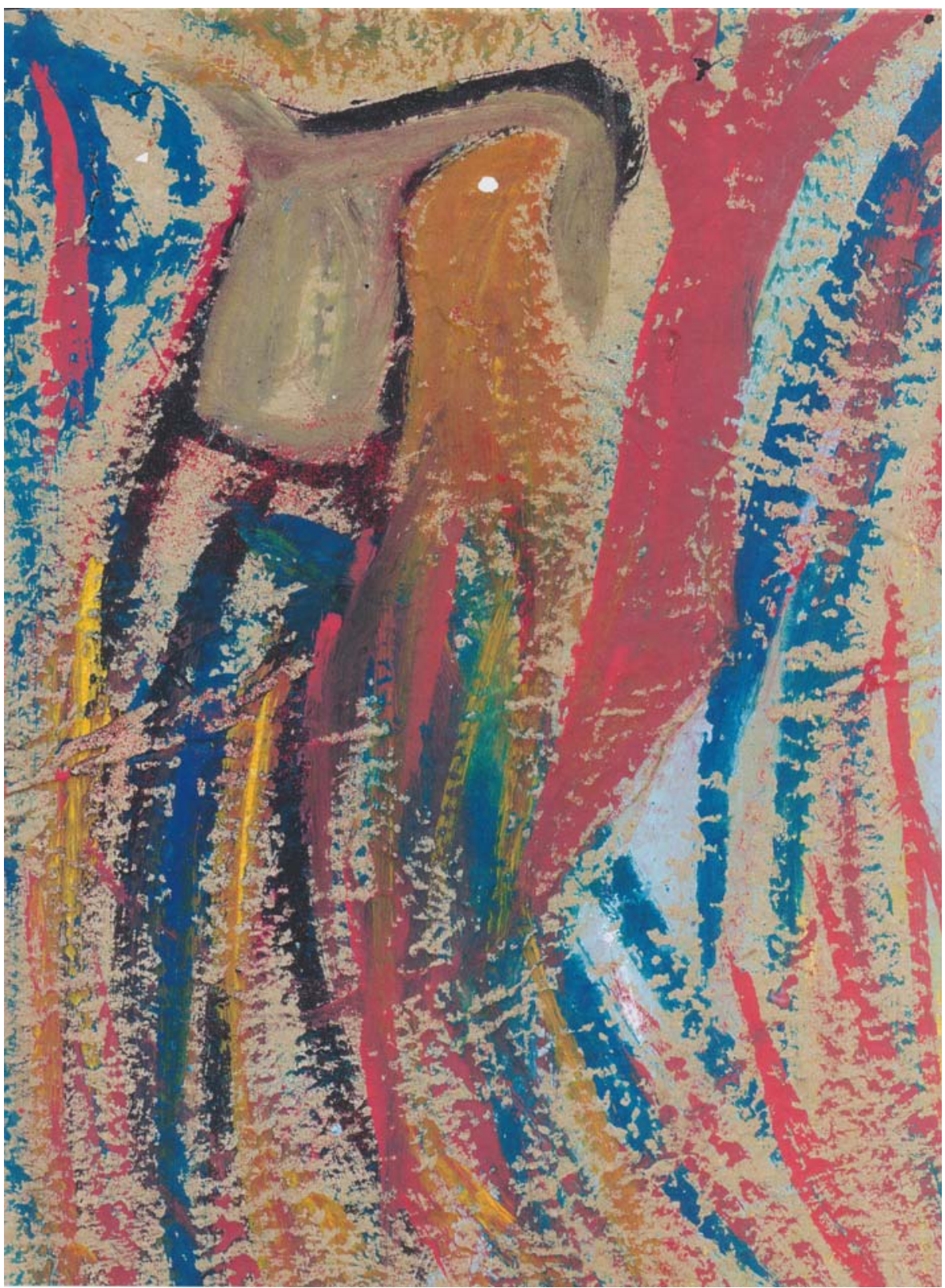




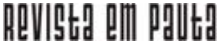

\} MARIA DO SOCORRO SANTOS - VASCONCELOS, E. M. \}

DOI: 10.12957/REP.2022. 63531

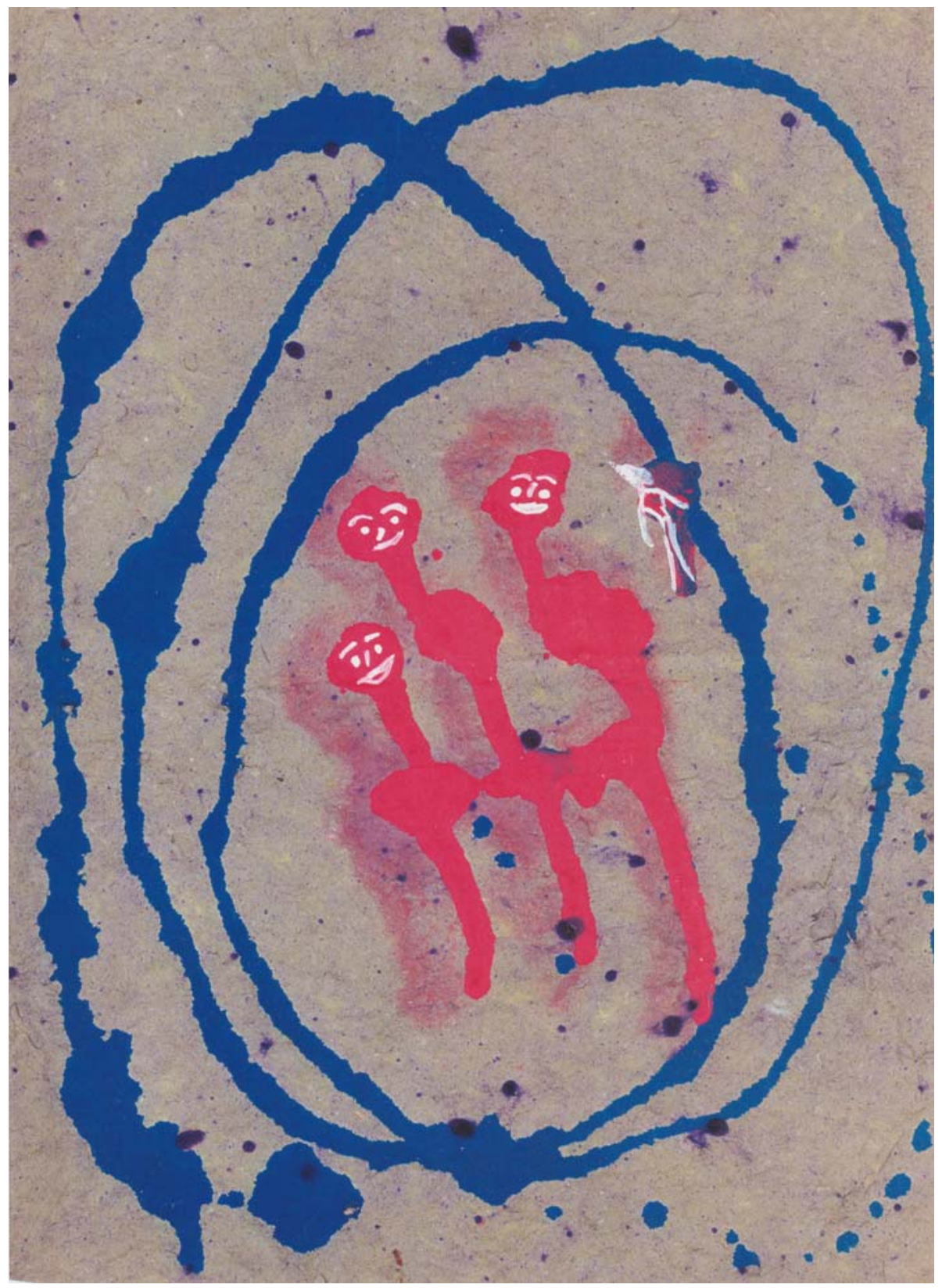

